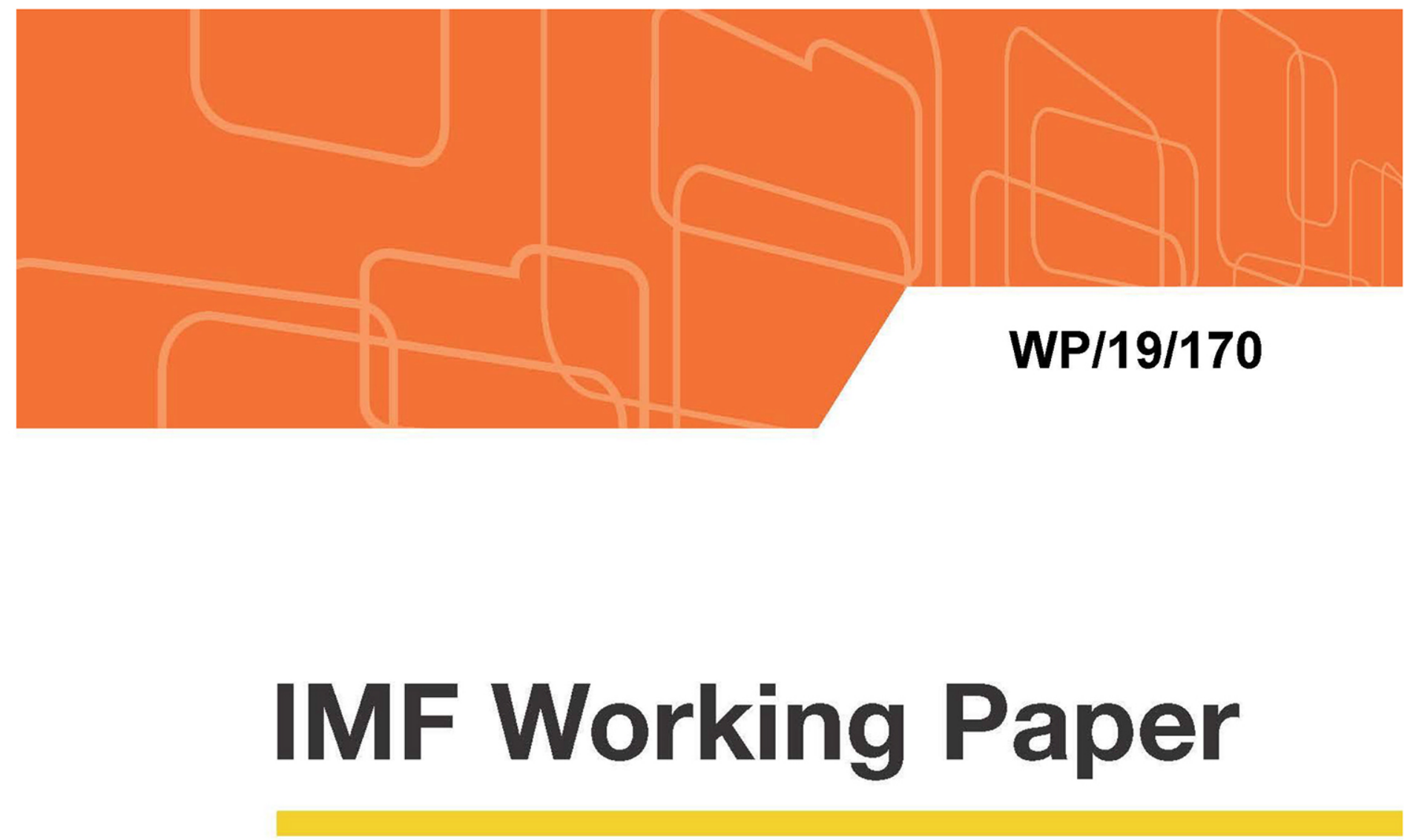

\title{
Public Sector Balance Sheet Strength and the Macro Economy
}

by Seyed Reza Yousefi 


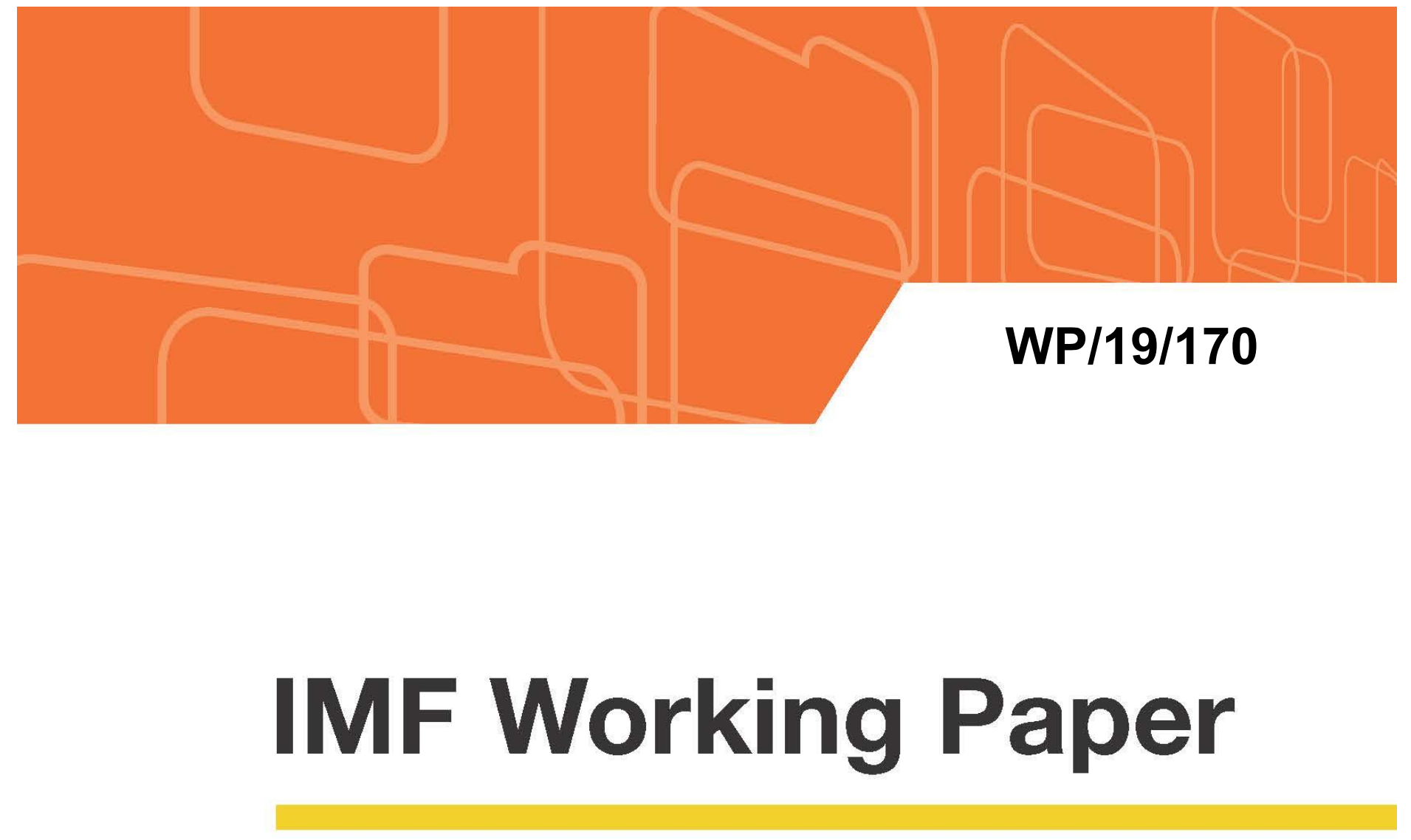

\section{Public Sector Balance Sheet Strength and the Macro Economy}

by Seyed Reza Yousefi

I N T E R N A T I O N A L M O N E T A R Y F U N D 


\title{
IMF Working Paper
}

Fiscal Affairs Department

\section{Public Sector Balance Sheet Strength and the Macro Economy \\ Prepared by Seyed Reza Yousefi*}

Authorized for distribution by Era Dabla-Norris

August 2019

IMF Working Papers describe research in progress by the author(s) and are published to elicit comments and to encourage debate. The views expressed in IMF Working Papers are those of the author(s) and do not necessarily represent the views of the IMF, its Executive Board, or IMF management.

\begin{abstract}
This paper introduces concepts of public sector balance sheet (PSBS) strength, taking into account different aspects of what governments own in addition to what they owe. It develops measures of PSBS strength and investigates their macroeconomic implications. Empirical estimations show that in their pricing of sovereign bonds, financial markets account for government assets and net worth in addition to their liabilities. Furthermore, economies with stronger public sector balance sheets experience shallower recessions and recover faster in the aftermath of economic downturns. This faster return to growth can be explained by the greater space for countercyclical fiscal policy in countries with stronger balance sheets.
\end{abstract}

JEL Classification Numbers: H50, H60, H63

Keywords: Public sector balance sheet, Fiscal policy, Net financial worth, Net worth

Author's E-Mail Address: syousefi@imf.org

\footnotetext{
* This paper was undertaken with the guidance of Jason Harris and Alexander F. Tieman. I would like to thank Lorenzo Forni, Abdelhak Senhadji, Era Dabla-Norris, Catherine Pattillo, Salvatore Dell'Erba, Francesca Caselli, and Suman Basu for their very helpful comments and suggestions, and Nisreen Zaqout and Juliana Gamboa Arbelaez for excellent research assistance.
} 
ABSTRACT

I. INTRODUCTION

II. MEASURES OF PSBS STRENGTH AND STYLIZED FACTS ______

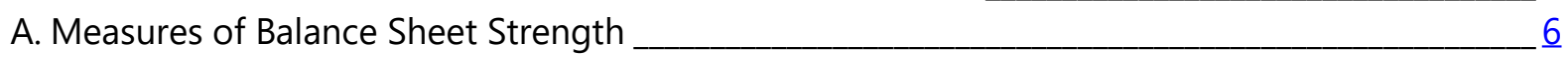

B. Stylized Facts________________________________________________________________

III. PSBS STRENGTH AND THE MACRO ECONOMY: EMPIRICAL EVIDENCE_____ 11

A. Sovereign Borrowing Cost ________________________________________

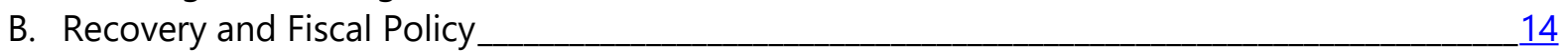

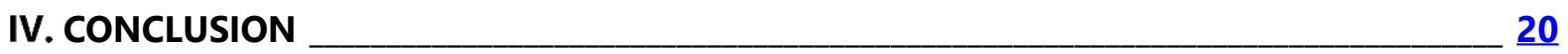

REFERENCES _______________________________________________________________

ANNEX: BALANCE SHEET STRENGTH: METHODOLOGY ____________ 25

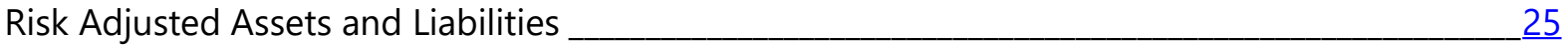

BOX

1. Country Case: Evolution of Public Sector Balance Sheet in Kazakhstan ________________

FIGURES

1. General Government Balance Sheets: Assets and Liabilities, 2016 _______

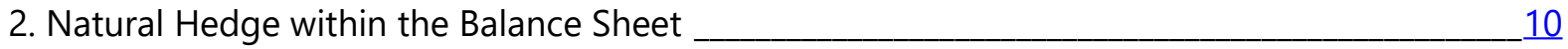

3. Quantifying the Impact of a 10 Percentage Point of GDP Change on Yields________ 14

4. Recovery and Fiscal Policy in the Aftermath of Economic Recessions________________________

\section{TABLES}

1. Government Balance Sheet and Sovereign Bond Yields 13

2. Recovery and Fiscal Policy in the Aftermath of Economic Recessions

3. Robustness Check: Recovery and Fiscal Policy in the Aftermath of Economic Recessions

\section{APPENDIX TABLES}

1. Government Balance Sheet and Sovereign Bond Yields (Concurrent Variables) $\underline{23}$

2. Government Balance Sheet and Sovereign Bond Yields (Random Effects) 


\section{INTRODUCTION}

Balance sheets are central to the analysis of corporates and households but are not used much in the assessment of the public sector. Economic analysis of the strength of corporates or households normally starts by looking at the entity's balance sheet. These balance sheets present a detailed overview of the stock of both liabilities and assets. In contrast, most analysis of the public sector focuses on government debt and deficits, paying at most cursory attention to some asset components and often not incorporating public corporations. Such analysis therefore neglects large swaths of the public sector.

The literature on public sector strength and risks has mainly focused on the macroeconomic implications of gross government debt. Studies examine the impact of government debt on spreads (Akitoby and Stratmann (2008), Ardagna and others (2007), Dell'Erba and others (2013), Jaramillo and Weber (2013)), and whether public debt buildup is associated with deeper and longer recessions (Bernardini and Forni (2018) and IMF (2016)). Economic theory suggests that an increase in government debt increases sovereign default risk, which would lead to higher yields to compensate investors for taking higher risks (see, e.g., Gruber and Kamin, 2012). In contrast, containing gross debt helps build confidence in government solvency and liquidity, especially during economic downturns.

Limited attention, however, has been paid in the existing literature to public assets and net worth as sources of macroeconomic strength. Some studies account for the government's asset base. For instance, Gruber and Kamin (2012), Chinn and Frankel (2005), Haugh and others (2009), Hadzi-Vaskov and Ricci (2016), and Henao-Arbelaez and Sobrinho (2017) look at debt net of (liquid) financial assets and investigate the impact of this net debt on spreads, risk premia and interest rates. In particular, Hadzi-Vaskov and Ricci (2016) find that, in emerging market economies, net debt can explain the impact of indebtedness on spreads better than gross debt. Moreover, government balance sheets have been used in fiscal analysis before, for instance in Buiter (1983), Allen and others (2002), and Traa and Carare (2007), although these efforts were hampered by data limitations. ${ }^{1}$ Individual asset categories have also been analyzed-natural resources in IMF (2012), nonfinancial assets in Bova and others (2013), and financial asset returns in Seiferling and Shamsuddin (2015) —and stock-flow adjustments were discussed in Jaramillo and others (2017). The lack of more comprehensive study of the public sector balance sheet (PSBS) can largely be attributed to the scarcity of data.

\footnotetext{
${ }^{1}$ In fact, the move toward compiling government balance sheets started much earlier, as evidenced by the publication of the central government balance sheet in Weimar Germany (Finanzministerium, 1933) and a questionnaire on government balance sheets from the League of Nations (1938).
} 
This paper expands the literature by analyzing the entire public sector balance sheet and its components. ${ }^{2}$ In principle, public financial and nonfinancial assets should matter for risk and resilience. This is all the more so for assets that are transparently accounted for and for highly liquid assets with stable valuations. This paper provides such a view by gauging the impact of balance sheet strength on sovereign yields and economic resilience. Specifically, the paper addresses the following questions. What constitutes a strong public sector balance sheet? Does public sector balance sheet strength have macroeconomic consequences, beyond the standard effects of debt discussed in the literature? Are governments with stronger balance sheets better able to engage in countercyclical fiscal policy during recessions? And lastly, do financial markets take account of assets and balance sheet strength?

To address these questions, the paper introduces measures of balance sheet strength and investigates how cross-country differences in balance sheet strength impact macroeconomic outcomes. Specifically, it analyzes whether countries with stronger balance sheets fare better in the aftermath of recessions, adding further aspects to Reinhart and Rogoff (2010). It also explores the response of financial markets to balance sheet strength and investigates whether they could explain movements in government bond yields beyond gross debt.

The paper contributes to the literature in three ways. First, it introduces a comprehensive set of measures of balance sheet strength and derives them for a large set of countries. Second, it employs these measures to gauge to what extent financial markets consider governments' asset positions. Third, it establishes that public sector balance sheet strength is a determinant of macroeconomic resilience. Stronger balance sheets provide governments more freedom to engage in countercyclical policy by increasing spending during downturns. As a result, countries with strong balance sheets experience shallower and shorter recessions.

The remainder of this paper is organized as follows. The next section introduces measures of public sector balance sheet strength and provides some stylized facts. Section III studies the impact of balance sheet strength measures on government bond yields. Section IV investigates whether countries with stronger balance sheets experience shallower and shorter recessions compared with those with weaker balance sheets. Finally, Section V concludes.

\footnotetext{
2 The public sector balance sheet encompasses all resident institutional units that are deemed to be controlled by the government. It includes all government units, such as departments, agencies, and nonprofit institutions controlled by the government, as well as corporations controlled by a government unit or another public corporation, including corporations that operate in both the financial and non-financial sectors of the economy (Alves and others 2019). Therefore, the institutional coverage for the public sector balance sheet is defined as general government, central bank, financial public corporations and nonfinancial public corporations, all consolidated for cross-holdings of assets and liabilities.
} 


\section{Measures of PSBS Strength and Stylized Facts}

The PSBS data compiled by IMF (2019) allow for the calculation of several indicators ${ }^{3}$ to measure balance sheet strength. Balance sheet strength measures are derived from both the asset and liability side of the balance sheet and their components. The specific measures introduced in this study are size of balance sheet, net worth, net financial worth, risk-adjusted assets and liabilities, net liquidity assets, net foreign exchange assets, and degree of natural hedging, all introduced in detail in Section II.A below.

\section{A. Measures of Balance Sheet Strength}

The following measures of balance sheet strength are used:

Size of Balance Sheet. The size of balance sheet is defined as the sum of the size of assets and liabilities (excluding net worth), in percent of GDP. Balance sheets with larger assets or liabilities are normally exposed to large valuation changes. Valuation changes may expose the economy to macroeconomic risks, depending on the source of vulnerabilities and the nature of valuation changes. For instance, exposure to valuation changes in equity markets and pension liabilities may amplify the impact on public finances (see, e.g., Brede and Henn 2018).

Solvency - Net (Financial) Worth. Net worth is a measure of solvency, comparable to the equity position of a corporation. It is calculated as total assets minus total liabilities, expressed in percent of GDP. ${ }^{4}$ While providing a snapshot of solvency, it suffers from the various valuation issues that accompany the constituent parts of the balance sheet, particularly stemming from nonfinancial assets. Furthermore, it does not distinguish between assets that can be sold to meet financing needs, and assets that are not marketable. Net financial worth is calculated as total financial assets less liabilities, expressed in percent of GDP. In general, financial assets and liabilities can be more reliably valued and are more readily marketable than nonfinancial assets. A measure for net worth excluding pension-related liabilities is also introduced. These solvency measures reflect static stock positions and hence do not take account of the state's largest assets and liabilities: its power to raise revenue in the future and its obligation to spend money on providing goods and service to the population. These future revenue and expenditure are

\footnotetext{
${ }^{3}$ See Alves and others (2019) for details on data sources, definition and methodology.

${ }^{4}$ While the same in accounting terms, the treatment of the concept of net worth in general government or the public sector is different from that in corporate finance. Governments, unlike corporations, do not have the goal to maximize their net worth. In addition, the public sector can function with negative net worth for very long periods of time, in contrast to the corporate sector, where such a state would usually trigger bankruptcy.
} 
incorporated in the intertemporal public balance sheet (see e.g. IMF 2018, Traa 2006, or Velculescu 2010), which, however, is not the focus of this paper. ${ }^{5}$

Risk-adjusted Assets and Liabilities. These indicators provide a guide to the volatility (and hence inherent risk) of both sides of the balance sheet. Risk-adjusted assets and liabilities provide measures of the assets and liabilities corrected for their riskiness or underlying volatility. The measures are based on estimates of the volatility of each asset (liability) class relative to the sum of the volatilities of all asset and liability components. Technical details about the derivation of these indices are discussed in detail in the Annex.

Liquidity Mismatch. The liquidity mismatch is measured using the "net liquid assets" indicator, which is calculated as current assets less current liabilities - that is, assets or liabilities that are maturing within one year-expressed in percent of GDP to reflect the materiality of the mismatch. ${ }^{6}$ It is a measure of whether the public sector has sufficient liquid assets to support its short-term financing needs.

Currency Mismatch. Currency mismatches are assessed using the "net foreign exchange assets" indicator, which shows the net impact of exchange rate fluctuations on the balance sheet. It is calculated as foreign exchange denominated assets less foreign exchange denominated liabilities, expressed in percent of GDP to reflect the materiality of foreign exchange mismatches. ${ }^{7}$

Natural Hedge. The natural hedge is a measure of volatility calculated as the variance of valuation changes in net financial worth relative to the variance of valuation changes in financial assets and liabilities. It measures the covariance between the valuation changes in assets and liabilities, both expressed in percent of GDP, normalized by the size of the movements in assets and liabilities. The measure can be decomposed into two parts: how correlated the financial assets and liabilities are; and whether there is a mismatch between the sizes of financial assets and liabilities. Technical details of the derivation of the index are discussed in the Annex.

\section{B. Stylized Facts}

Balance sheet measures provide a rich picture of fiscal health. Balance sheet size, composition and solvency vary considerably across our sample of 69 countries (Figure 1, panel 1). ${ }^{8}$ The data

\footnotetext{
${ }^{5}$ The intertemporal public sector balance sheet adds the net present values of all future fiscal balances to the static PSBS. However, the computation of intertemporal solvency would require many assumptions, e.g., in constructing the future fiscal path, discount factor, and age-related spending.

${ }^{6}$ A more nuanced definition of liquidity would also account for the ability of the government to sell the assets without an adverse impact on price. Data limitations at present preclude reporting on this basis.

${ }^{7}$ Where available, foreign exchange-linked assets and liabilities are included.

8 These estimates cover a broader range of countries but are less comprehensive than those presented in Figure 1. For 62 of these countries, the figure contains general government data, while for the remaining 7 that
} 
are compared for general government, and central government if general government data is not available. Excluding natural resource assets and pension liabilities, assets average 102 percent of GDP, ranging from 398 percent of GDP in Norway to 21 percent of GDP in India, roughly evenly split between financial and nonfinancial assets. ${ }^{9}$ Against these assets stand average liabilities of 71 percent of GDP. As a result, static net worth in the sample varies from 111 percent of GDP in Greece to 348 percent of GDP in Norway, with an average positive net worth of 31 percent of GDP. Net financial worth averages -23 percent of GDP, with Greece and Norway again at the extremes.

A simple comparison of the evolution of assets and liabilities reveals that gross debt alone would only provide part of the picture of the well-being of the public sector. Calculations of the evolution of gross debt and net financial worth among the European countries reveals that there is significant divergence between gross debt and net financial worth. Gross debt misses average (median) of 14.3 (9.1) percent of GDP in the absolute change in public wealth over the 2000-2015 period.

Mismatches in the balance sheet and other risks beyond solvency show a similarly heterogeneous picture. For a subsample of countries, the data can shed light on balance sheet risks, using measures of liquidity and foreign exchange mismatches, risk-weighted assets and liabilities, and natural hedges:

- $\quad$ Risk-adjusted assets and liabilities: Financial assets are more volatile than liabilities for almost all countries in the sample (Figure 1, panel 4). This is primarily because financial assets include inherently volatile components such as equities and other investment, often held in social security funds, whereas many liabilities are government debt securities that are repaid at maturity and assessed at face value. ${ }^{10}$ Thus, a country like Norway, with high investments in financial markets through its sovereign wealth fund, features a high average risk weight on its assets and hence a relatively large difference between total assets and risk-adjusted assets, while the risk adjustment for liabilities is small. The combination of high exposure to volatile assets and relatively stable liabilities can result in rapid changes in solvency and liquidity.

\footnotetext{
data is only available for central government. To make the data comparable across countries the figure excludes land and natural resource assets and pension liabilities, implying lower estimates of net worth.

${ }^{9}$ Based on central government data for India, which may partly explain the small number.

${ }^{10}$ For this analysis, debt securities are measured at face value, as they are almost always repaid at maturity. It is because using market prices for debt securities increases their volatility - by 0.6 percent of GDP on average. The use of nominal value would have been preferred if data were available. It is because face value provides a good measure of the debt security value at maturity while nominal value, which is different from market value, provides a good measure of the debt security value throughout all its life (since inception to maturity).
} 
Figure 1. General Government Balance Sheets: Assets and Liabilities, 2016 (Percent of GDP)

1. Total Assets and Liabilities

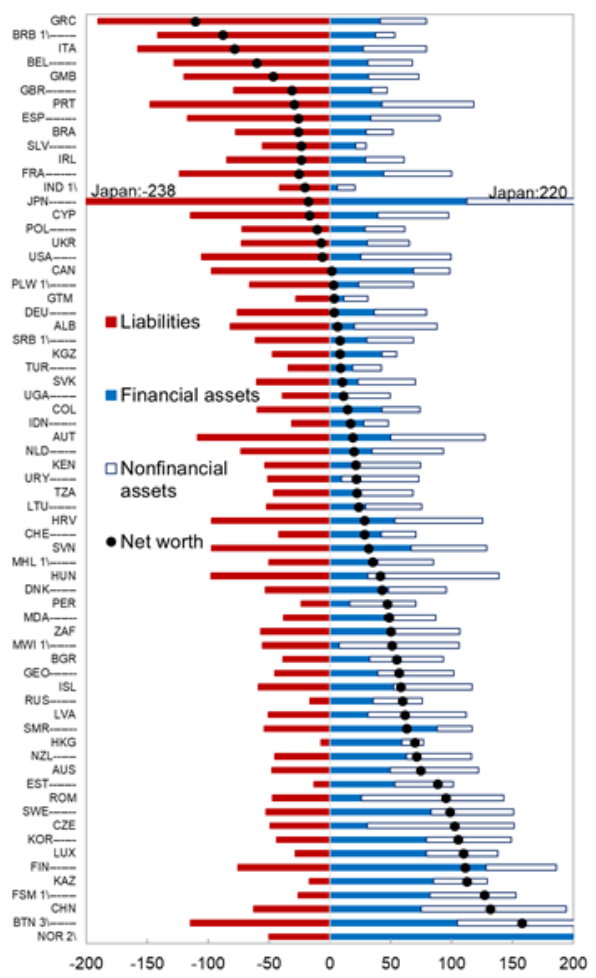

3. Foreign Exchange Assets and Liabilities

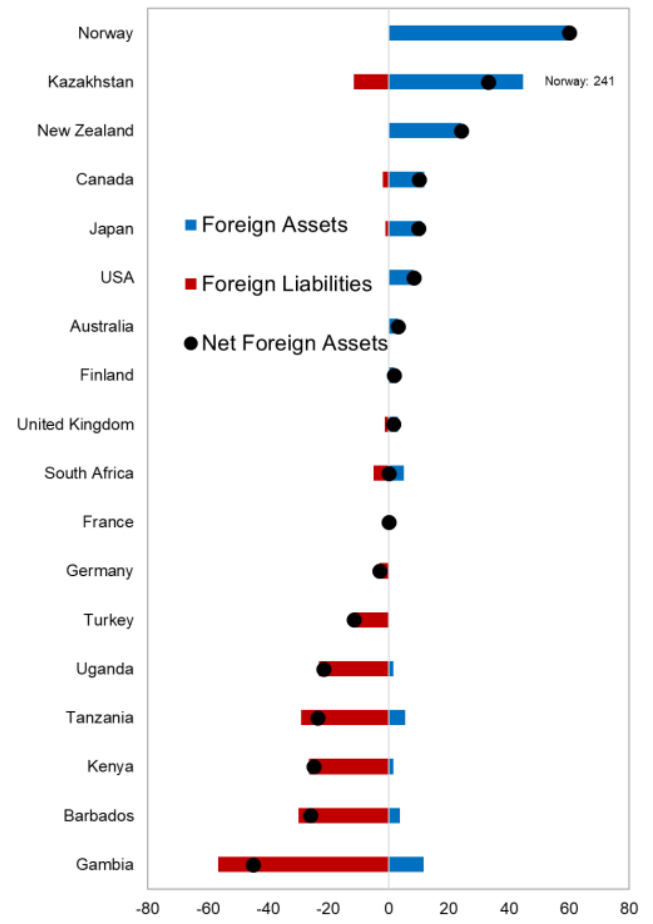

2. Liquid Assets and Liabilities

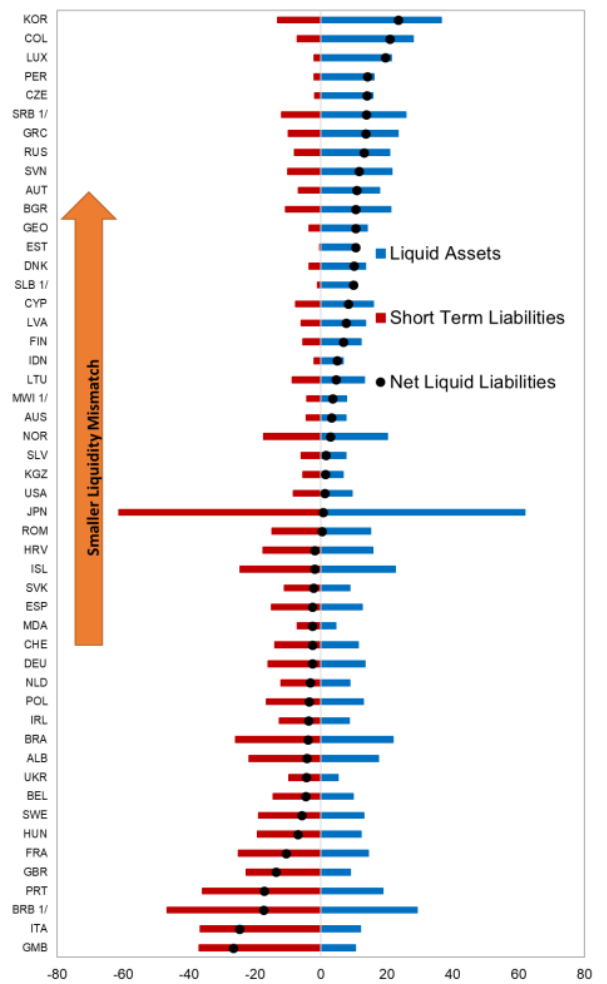

4. Risk-Adjusted Assets and Liabilities

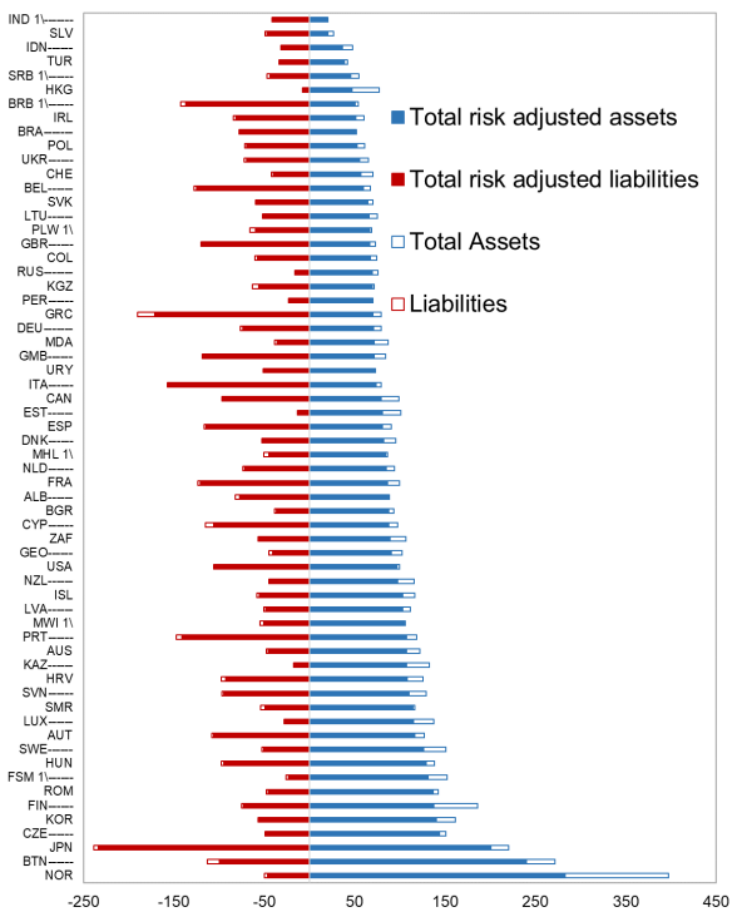

1/ Central government data. 2/ Norway's total assets are 397 percent of GDP. 3/ Bhutan's total assets are 272 percent of GDP.

Note: In all panels, the data exclude land and natural resources assets and pension liabilities. 
- $\quad$ Foreign Exchange: Many countries borrow in foreign currency and thus have significant foreign exchange liabilities. Against these liabilities, some have significant foreign exchange assets that need to be taken into account when assessing exchange rate risk. ${ }^{11}$ Net foreign exchange exposure can reveal significant mismatches, showing for instance that Barbados, The Gambia, Kenya, Tanzania, and Uganda all have significant foreign exchange debt with little compensating foreign exchange assets (Figure 1, panel 3). In contrast to foreign exchange debt data, data on foreign exchange assets are scarce, which limits the analysis.

- Liquidity: General government liquid assets average 16 percent of GDP across the sample (Figure 1, panel 2), ranging from Moldova (5 percent of GDP) to Japan (62 percent of GDP). Combined with short-term liabilities of 14 percent of GDP on average, countries' net liquid positions vary from -27 percent of GDP to 23 percent of GDP, with The Gambia, Italy and Barbados exhibiting the largest mismatches.

- Natural Hedge: Many countries in the sample show significant co-movement between the valuation changes of assets and liabilities. These co-movements often dampen the valuation changes of net financial worth, providing a natural hedge in the balance sheet (Figure 2, shown in green). In some countries, valuation changes in assets and liabilities reinforce each other, amplifying the impact on net financial worth (shown in red).

Figure 2. Natural Hedge within the Balance Sheet

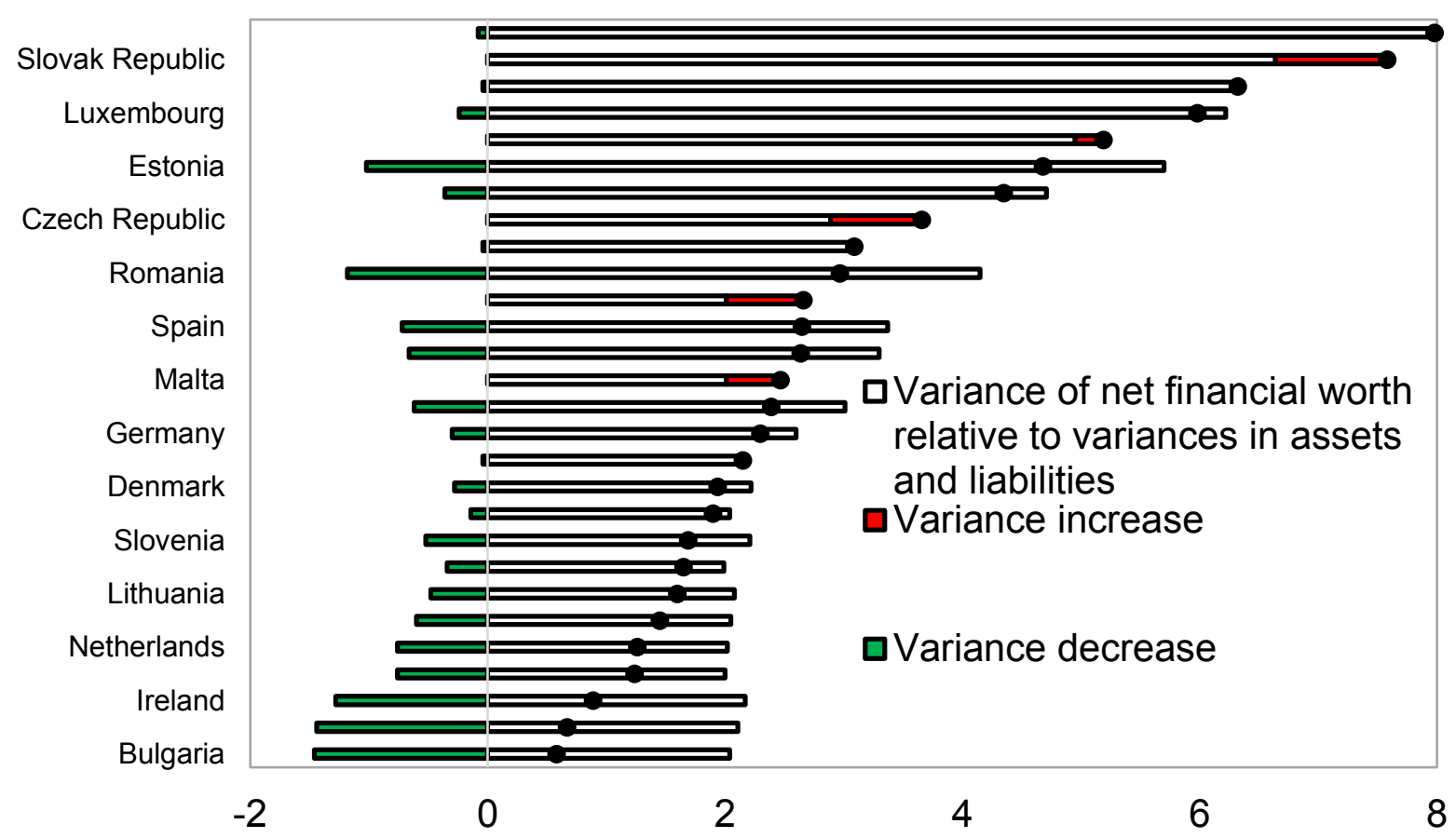

\footnotetext{
${ }^{11}$ Central bank foreign exchange reserves are excluded from this analysis.
} 


\section{PSBS StRength AND the MACRo ECONOMY: Empirical Evidence}

\section{A. Sovereign Borrowing Cost}

This section investigates whether public sector assets influence governments' borrowing costs. It describes the empirical specification to study the impact of different balance sheet components on government bond yields including accounting for the asset side of the public sector balance sheet. The estimation includes the following fixed effects panel specification:

$$
y_{i t}=\boldsymbol{\beta} \boldsymbol{x}_{i t}+\gamma z_{i t}+c_{i}+\lambda_{t}+\epsilon_{i t}
$$

where $y_{i t}$ is the long-term government bond yield of country $i$ in year $t$; and $\boldsymbol{x}_{\boldsymbol{i}}$ a balance sheet variable, main variable of interest. Long term bond yields are obtained from Thomson Reuters Datastream Economics database ${ }^{12}$, and the balance sheet data are extracted from IMF (2019). These balance sheet indicators include general government gross debt, total assets, financial assets, net worth, and net financial worth, all lagged to minimize the bias originating from reverse causality. ${ }^{13}$ All balance sheet indicators are based on general government data from the PSBS dataset introduced in the IMF (2019) and October 2018 Fiscal Monitor (IMF 2018), except for gross debt, which is extracted from the World Economic Outlook database. All variables are expressed as percent of GDP. The set of variables $\boldsymbol{z}_{\boldsymbol{i t}}$ controls for the frequently-used possible channels in the literature through which macro-fiscal conditions may affect sovereign bond yields. The control variables include the growth rate of real per capita GDP, the US 10-year bond yield, the average inflation rate in country $i$, the short-term interest rate, and the general government primary balance. ${ }^{14}$ These variables control for various macro-fiscal channels which could affect sovereign bond yields. Countries with higher rates of economic growth have generally greater tax capacity to service debt; inflation is a proxy for the impact of inflation on lowering the rate of return on bonds; short-term interest rate controls for the stance of monetary policy; and general government primary balance measures the direction of fiscal policy and debt sustainability. Finally, $c_{i}$ and $\lambda_{t}$ represent country and time fixed effects, respectively. The sample period is 2001-2016 and we perform the estimation for the full sample of countries as well as for advanced economies and emerging markets separately. ${ }^{15}$

\footnotetext{
12 These are the yields for 10-year bonds for most countries, except for Belgium and Cyprus (6 year), Kazakhstan (up to 5 year), Kyrgyz Republic and Moldova (2 years), Slovenia (11 year), and the UK and the US (20 year).

${ }^{13}$ Assets excluding land and other natural resources, and liabilities excluding pension liabilities, both for reasons of cross-country comparability.

14 Foreign buyers of emerging market sovereign debt in particular may also care about public foreign exchange assets. Ideally these would be included in the set of control variables, but they are not because of data limitations.

${ }^{15}$ Advanced economies in the sample are Australia, Belgium, Canada, Czech Republic, Cyprus, Denmark, Finland, France, Germany, Greece, Iceland, Ireland, Italy, Japan, Luxembourg, the Netherlands, New Zealand, Norway, Slovak Republic, Slovenia, Spain, Sweden, Switzerland, the United Kingdom, and the United States. Emerging
} 
The estimation results show that financial markets seem to account for government assets and net (financial) worth when pricing sovereign bonds. Phrased differently, balance sheet indicators beyond gross debt matter for sovereign yields. Specifically, total or financial assets are highly significant variables, both as stand-alone balance sheet variables and in regressions together with gross debt. Similarly, net (financial) worth is a highly significant stand-alone explanatory variables for the pricing of sovereign bonds (Table 1). These results are most clear in the full sample and the sample consisting of advanced economies, while significance is generally lower in the much smaller sample consisting solely of emerging markets. The results are robust to using a different sample period, excluding the crisis years. However, one should note that these results do not prove causality, as the identification does not fully address concerns regarding the endogeneity and reverse causality.

The magnitude of the impact of net (financial) worth on yields is comparable to the impact of gross debt. In the whole sample, a one percent of GDP increase in government net (financial) worth lowers yields by some 1.5 (0.6) bps, compared to a 0.7 bps increase in yield when gross debt increases by the same amount. Note that, while of the expected sign, the impact of net financial worth not statistically significant in the full sample. Net (financial) worth impacts sovereign bond yields in advanced economies in a similar way - with higher statistical significance - where a one percent of GDP increase in either net financial worth or net worth can lower yields by some $1 \mathrm{bp}$. The impact is less sizeable for the sample of advanced economies, which suggests that it could be due to higher yields in the rest of sample, i.e., emerging markets (also supported by the random effects regressions reported in Appendix Table 2) ${ }^{16}$. These results are consistent with Hadzi-Vaskov and Ricci (2016) and Gruber and Kamin (2012), who find that financial markets seem to account for government assets and net worth when pricing sovereign bonds; and that the effect of fiscal variables of interest (gross/net debt, assets) on bond yields/spreads is larger for emerging market economies than advanced economies.

Quantifying these impacts ${ }^{17}$, Figure 3 depicts the impact of a 10 percentage point of GDP change in gross debt, assets, and net worth on sovereign bond yields for the full sample as well as advanced economies. The increase in gross debt would increase yields by 6.9 (8.3) bps in the full sample (advance economies). An increase in both gross debt and total assets of 10 percentage points of GDP would increase yields by 15.7 (8.1) bps and decrease by 26.7 (9.1) bps respectively, implying that the total assets also affect yields. Finally, a 10 percent of GDP increase in net worth lowers yields by 15.4 (9.5) bps in the full sample (advance economies). The results are robust to

\footnotetext{
markets included in the sample are Croatia, Hungary, India, Indonesia, Kazakhstan, Kyrgyz Republic, Moldova, Poland, and South Africa.

16 The fixed effects regressions for the sample of emerging markets (EMs) are not feasible due to the small sample size of the countries.

${ }^{17}$ The quantification should be treated by caution as they are only suggestive and depend on the set of control variables, sample of countries, etc.
} 
the inclusion of concurrent explanatory variables (see Appendix Table 1). They are also robust to a random effects specification (Appendix Table 2).

The findings suggest that financial markets pay attention to public sector assets in addition to liabilities. Given data availability, markets presumably focus mainly on net financial worth, in particular in advanced economies. However, even when precise data are lacking, markets may pay attention to (rough estimates of) non-financial assets such as natural resources when assessing macroeconomic sustainability. ${ }^{18}$ This implies that that that lowering public debt through asset decumulation would not help countries lower sovereign bond yields. The empirical exercise further supports the view that countries should not only report developments in public debt but also carefully monitor and forecast their position in financial assets and net (financial) worth.

Table 1. Government Balance Sheet and Sovereign Bond Yields

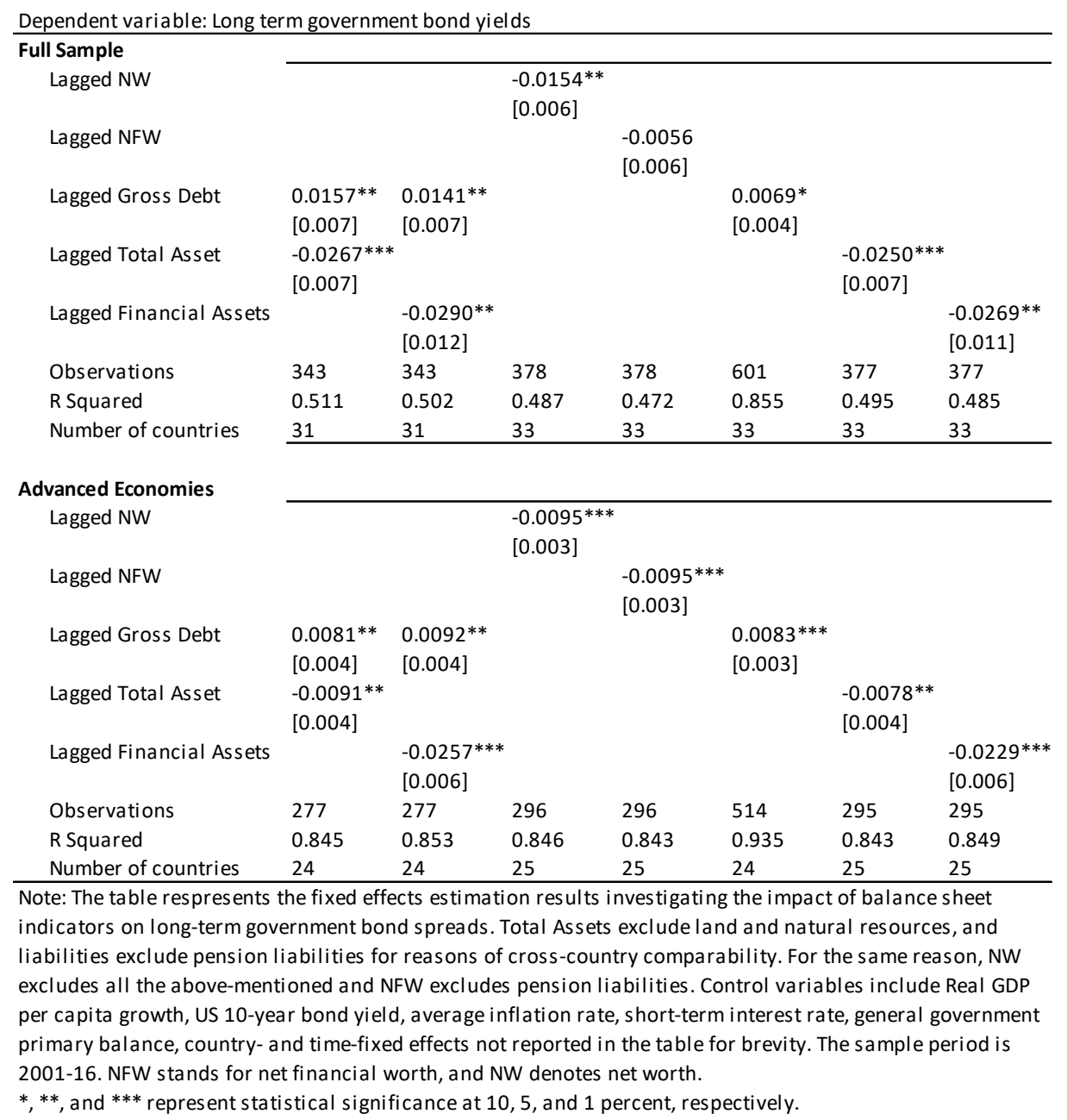

\footnotetext{
${ }^{18}$ It is also possible that the correlation we find between net worth and spreads is simply picking up the impact of net financial worth rather than net worth. As the value of nonfinancial assets changes only slowly over time, the two often move in tandem.
} 


\section{Figure 3. Quantifying the Impact of a 10 Percentage Point of GDP Change on Yields (bps)}
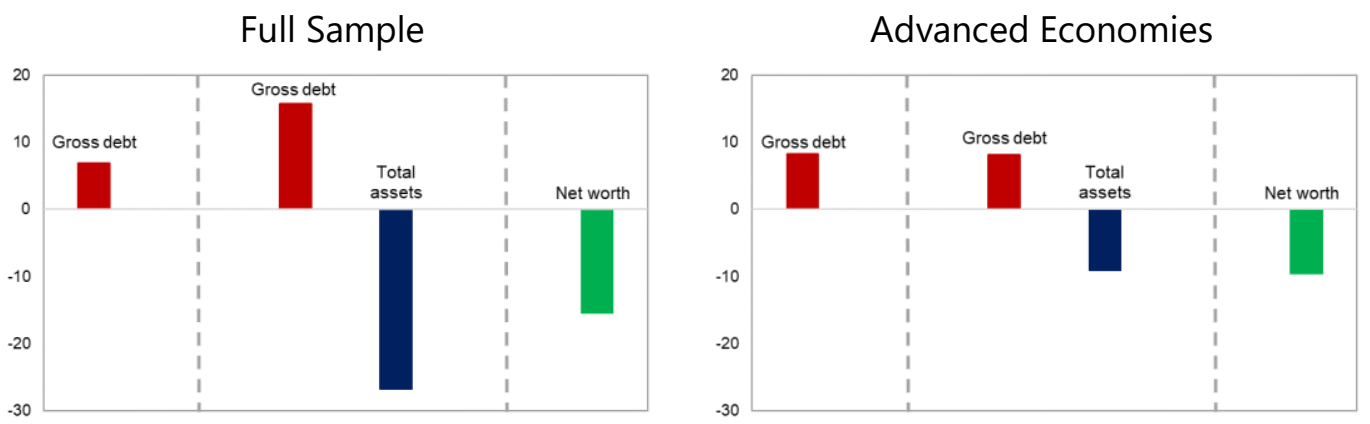

Note: Calculations are based on the coefficients in Table 1.

\section{B. Recovery and Fiscal Policy}

Public sector balance sheet strength is a measure of the health of public finances. Therefore, one might wonder whether countries with healthier public finances have more room to engage in countercyclical fiscal policy in the aftermath of recessions, and if they experience shallower recessions and a faster return to growth as a result.

The analysis of the impact of balance sheet strength on the macro economy is based on the local projection method (LPM). The LPM was introduced by Jordà (2005) and Jordà, Schularick, and Taylor (2016), and allows for local estimations for each forecast horizon. It has the advantage of providing impulse response coefficients with simple inferences by estimating a single-equation OLS (Ordinary Least Squares) for each forecast horizon of interest. The model provides an ideal empirical framework to investigate whether countries with certain characteristics (here strong versus weak balance sheets) respond differently to the episodes of recessions. Furthermore, the model estimates the varying effects of recessions on economic growth and government spending, depending on balance sheet strength. These effects are over and above the effects stemming from private and public debt, as these variables are controlled for in the regression.

This study uses a sample of 17 advanced economies for which long time series data are available. ${ }^{19}$ The data covers 1970-2015 and come from various sources: Data on net financial worth are taken from the World Inequality Database (WID), which provides long time series for the advanced economies. ${ }^{20}$ Some of the series are based on official statistics, while others are estimates based on different data sources available (fiscal data, survey data and national accounts). Real per capita GDP is extracted from the World Economic Outlook and Penn World

\footnotetext{
${ }^{19}$ The data are annual and cover the following countries: Australia, Canada, Czech Republic, Denmark, Finland, France, Germany, Greece, Italy, Japan, Republic of Korea, Netherlands, Norway, Spain, Sweden, United Kingdom, and the United States.

${ }^{20}$ The World Inequality Database is available at http://wid.world/wid-world/. The correlations between (changes in) net financial worth in the WID and the PSBS dataset introduced in IMF (2019) are positive and significant at the 1 percent level.
} 
Table, whereas government spending data is sourced from Mauro and others (2015). Data on public and private debt are sourced from IMF (2016) and Bernardini and Forni (2017). Private debt is defined as bank's claims on the private sector collected from the International Finance Statistics (IFS) ${ }^{21}$, and data on public debt ${ }^{22}$ is from an updated version of the Abbas and others (2010) historical debt database.

The baseline regression is as follows:

$y_{i, p+h}-y_{i, p}=\theta_{S} d_{i, p}^{S}+\theta_{W} d_{i, p}^{W}+\beta_{h}^{S, P r}\left(d_{i, p}^{S} x_{i, p}^{P r}\right)+\beta_{h}^{W, P r}\left(d_{i, p}^{W} x_{i, p}^{P r}\right)+\beta_{h}^{S, P u}\left(d_{i, p}^{S} x_{i, p}^{P u}\right)+$
$\beta_{h}^{W, P u}\left(d_{i, p}^{W} x_{i, p}^{P u}\right)+\beta_{h}^{S, P r P u}\left(d_{i, p}^{S} x_{i, p}^{P r} x_{i, p}^{P u}\right)+\beta_{h}^{W, P r P u}\left(d_{i, p}^{W} x_{i, p}^{P r} x_{i, p}^{P u}\right)+\sum_{l=1}^{L} \gamma_{h, l} Y_{i, p-l}+\alpha_{i, h}+\epsilon_{i, p+h}$,

where the dependent variable $y_{i, p+h}-y_{i, p}$ is the cumulative growth rate (log difference) in real GDP or real government spending, both in per capita terms in country $i, h$ years after the business cycle peak. Peak years are identified as the start of the recession according to Bry and Boschan (1971) definition; year $\mathrm{t}$ is the year as "peak year" if real per-capita GDP grows in year $t$ and drops in year $t+1$, i.e., the year followed by a year in which GDP declines. The dummy variables $d_{i, p}^{S}$ and $d_{i, p}^{W}$ denote respectively strong and weak balance sheets in the peak year. Strong (weak) balance sheets are defined as those with net financial worth above (below) the sample median. Following the analysis in IMF (2016), the variables $x_{i, p}^{P r}$ and $x_{i, p}^{P u}$ present the average annual change in the five years before the peak of private debt, and the level of public debt as a percent of GDP at the peak, respectively.

Due to the significant role of rapid buildup in private and public debt in the depth of economic slowdown and its recovery (Bernardini and Forni 2017), the specification also controls for the public and private debt and their interactions separately for the countries with weaker and stronger balance sheets ${ }^{23} . Y_{i, p-l}$ is the set of lagged control variables. Controls include two lags of real per capita GDP growth rates, government expenditures, public debt and private debt. ${ }^{24}$ Finally, $\alpha_{i, h}$ are country-year fixed effects, and $\epsilon_{i, p+h}$ denotes the error term. Standard errors are computed using the Driscoll and Kraay (1998) method to correct for heteroskedasticity, cross-

\footnotetext{
${ }^{21}$ Claims include items other than loans, all relatively minor, including financial derivatives, trade credit, and securities and shares. With the exception of shares, these items are considered part of debt.
}

22 From statistical point of view, public debt is different from public liabilities in that it excludes equity and investment fund shares, financial derivatives, and employee stock options. For developed countries, public debt refers to the general government debt in the form of debt securities, loans, special drawing rights, currency and deposits and other accounts payable, while for the emerging markets, it refers to budgetary central government debt in the form of debt securities and loans.

${ }^{23}$ For robustness checks, we also perform the regressions without these controls. The estimations are available upon request.

${ }^{24}$ We use a standard set of control variables from Bernardini and Forni (2017). This specification does not account for possible collinearity or nonlinear relations between the control variables and balance sheet strength dummies. 
sectional dependence and serial correlation. To allow for meaningful interpretation of $\theta_{S}$ and $\theta_{W}$ all right-hand side variables are transformed into differences from their pooled mean. In addition, $\alpha_{i, h}$ are normalized so that the sum of all country dummies be equal to zero, i.e., $\sum_{i=1}^{N} \alpha_{i, h}=0$, and the last country dummy is dropped to avoid multicollinearity. With these transformations, the coefficients $\theta_{S}$ and $\theta_{W}$ measure the average path of GDP in countries with stronger and weaker balance sheets

The analysis investigates post-recession the recovery and fiscal policy, by studying the conditional cumulated changes in GDP and real per-capita government expenditure from the start of economic recessions. It finds that countries with strong public sector balance sheets face shorter and shallower recessions (Table 2) and increase real per-capita expenditure after a recession. Figure 4 presents these results graphically. It distinguishes countries that entered the recession with a strong initial balance sheet (blue line) from those entering the downturn with a weak balance sheet (red line). The results on expenditure show a statistically significant difference between the coefficient for countries with a strong and weak balance sheet, with p-values below 5 percent starting from the second year. Results of the GDP regression are also significant, though the $p$ values for the test of the difference between the coefficients for countries with a strong and weak balance sheet are only below 5 percent in years 4 and 5 . This lower significance is likely due to the limited number of observations in the sample. However, given the very limited observations (53 observations only) the differences are promising.

These findings have important policy implications. When hit by a downturn, it is hard for an economy with a weak public sector balance sheet to return to growth. Countries with strong balance sheets, on the other hand, have greater fiscal space to increase public expenditure during a recession, and hence return to growth more quickly. This effect is beyond the channels of build-up of private and public debt in the boom period preceding the crisis as we control for those variables. The country case of Kazakhstan (see Box 1 ) illustrates how assets and natural hedge between assets and liabilities allowed the authorities to boost the economy by providing fiscal stimulus in the aftermath of the 2014 oil price shock.

These findings are robust to different control variables or even their absence. Excluding the $x_{i, p}^{P r}$ and $x_{i, p}^{P u}$ variables and their interactions does not qualitatively alter the results. This implies that our results are not driven by surges in public or private debt. The findings are also robust when we use net worth instead of net financial worth as indicator of balance sheet strength. Even excluding all control variables does not qualitatively alter our results (Table 3). 
Table 2. Recovery and Fiscal Policy in the Aftermath of Economic Recessions

\begin{tabular}{|c|c|c|c|c|c|c|c|c|c|c|}
\hline & \multicolumn{5}{|c|}{ Real GDP Per Capita } & \multicolumn{5}{|c|}{ Real Government Expenditure Per Capita } \\
\hline & Year 1 & Year 2 & Year 3 & Year 4 & Year 5 & Year 1 & Year 2 & Year 3 & Year 4 & Year 5 \\
\hline \multirow[t]{2}{*}{$\theta_{s}$} & $-1.60 * * *$ & $-0.77^{*}$ & $1.23 *$ & $4.29 * * *$ & $9.30 * * *$ & $3.90^{* * *}$ & $8.77^{* * *}$ & $14.69 * * *$ & $24.39 * * *$ & $33.46^{* * *}$ \\
\hline & $(0.32)$ & $(0.62)$ & $(0.60)$ & $(0.73)$ & (0.95) & (1.05) & (1.24) & (3.04) & (4.02) & (3.80) \\
\hline \multirow[t]{2}{*}{$\theta_{w}$} & $-2.78 * * *$ & $-2.84 * *$ & -0.70 & -0.06 & $2.67^{*}$ & 1.31 & 0.30 & 1.92 & $-11.31^{* *}$ & $-2.81^{*}$ \\
\hline & $(0.96)$ & $(1.13)$ & $(1.28)$ & $(1.31)$ & $(1.56)$ & $(2.21)$ & $(1.91)$ & $(2.24)$ & $(4.41)$ & $(1.99)$ \\
\hline \multirow[t]{2}{*}{$\beta_{h}^{S, P r}$} & 0.10 & $0.36^{* *}$ & $0.50 *$ & $0.53^{*}$ & $0.82^{* *}$ & 0.19 & $-0.79 *$ & $-1.34 *$ & 0.16 & 1.16 \\
\hline & $(0.16)$ & $(0.16)$ & $(0.38)$ & (0.39) & $(0.33)$ & $(0.32)$ & $(0.61)$ & $(0.72)$ & (1.28) & $(1.46)$ \\
\hline \multirow{2}{*}{$\beta_{h}^{W_{n} P_{r}}$} & $0.32 *$ & -0.24 & $-0.85 * *$ & $-0.90^{* *}$ & $-1.41^{*}$ & $-1.24 * *$ & $-0.72 *$ & $-2.04 * *$ & $-5.28 * * *$ & $-5.33 * * *$ \\
\hline & $(0.25)$ & $(0.24)$ & $(0.31)$ & $(0.41)$ & $(0.67)$ & $(0.46)$ & $(0.65)$ & $(0.72)$ & $(1.43)$ & $(1.60)$ \\
\hline \multirow[t]{2}{*}{$\beta_{h}^{S_{,} p_{u}}$} & $0.06 *$ & 0.01 & -0.01 & 0.04 & -0.10 & -0.12 & $-0.46^{* * *}$ & -0.16 & $-1.01^{* *}$ & $-1.60 * * *$ \\
\hline & $(0.04)$ & $(0.06)$ & (0.09) & $(0.12)$ & $(0.11)$ & $(0.15)$ & $(0.13)$ & $(0.25)$ & $(0.42)$ & $(0.14)$ \\
\hline \multirow[t]{2}{*}{$\beta_{h}^{W, P_{u}}$} & $0.03 *$ & -0.01 & $-0.07^{* *}$ & $-0.09 * *$ & $-0.13^{* * *}$ & $-0.11^{* *}$ & $-0.18^{* *}$ & $-0.36 * * *$ & $-0.34 * * *$ & $-0.34 * *$ \\
\hline & $(0.02)$ & $(0.02)$ & $(0.03)$ & $(0.03)$ & $(0.04)$ & $(0.04)$ & $(0.06)$ & $(0.10)$ & $(0.08)$ & $(0.13)$ \\
\hline \multirow[t]{2}{*}{$\beta_{h}^{S, P r P_{u}}$} & 0.01 & -0.02 & $-0.03^{*}$ & -0.03 & $-0.06 *$ & $-0.06^{* *}$ & 0.00 & $-0.04^{*}$ & $-0.25 * * *$ & $-0.31^{* * *}$ \\
\hline & $(0.01)$ & $(0.02)$ & $(0.03)$ & $(0.03)$ & $(0.03)$ & $(0.03)$ & $(0.04)$ & $(0.04)$ & $(0.07)$ & $(0.04)$ \\
\hline \multirow{2}{*}{$\beta_{h}^{W_{n} P_{r} P_{u}}$} & -0.01 & $-0.01^{*}$ & $-0.02 *$ & $-0.02^{* *}$ & $-0.02 * *$ & $-0.02 *$ & $-0.03^{* *}$ & -0.02 & $-0.11^{* *}$ & $-0.09 *$ \\
\hline & $(0.01)$ & $(0.01)$ & $(0.01)$ & $(0.01)$ & $(0.01)$ & $(0.02)$ & $(0.01)$ & $(0.03)$ & $(0.05)$ & $(0.04)$ \\
\hline $\mathrm{R}^{2}$ & 0.83 & 0.74 & 0.76 & 0.84 & 0.91 & 0.80 & 0.84 & 0.85 & 0.85 & 0.91 \\
\hline$\theta_{S}=\theta_{W}(p$ value $)$ & 0.34 & 0.12 & 0.26 & 0.03 & 0.01 & 0.42 & 0.01 & 0.01 & 0.00 & 0.00 \\
\hline Peaks & 53 & 53 & 52 & 52 & 42 & 53 & 53 & 52 & 52 & 42 \\
\hline
\end{tabular}

Note: The table reports the estimations using the Local Projections Model. The first five columns present the coefficients for real GDP per capita and the second five represent those for real government expenditure per capita as dependent variables (both cumulative changes starting from the peak before economic recessions). The regressions also include fixed effects and control variables that are not reported. Robust standard errors are reported in the second row of each line where ${ }^{*}, * *, * * *$ denote $p$-values less than 0.32 ( 1 standard deviation), 0.05 ( 2 standard deviations), and 0.01 (3 standard deviations) percent respectively. 


\section{Figure 4. Recovery and Fiscal Policy in the Aftermath of Economic Recessions}

1. Real Government Expenditure per Capita

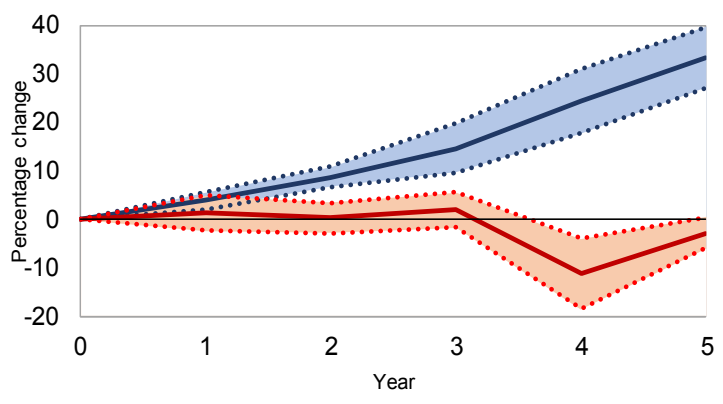

— Strong balance sheets
2. Real GDP per Capita

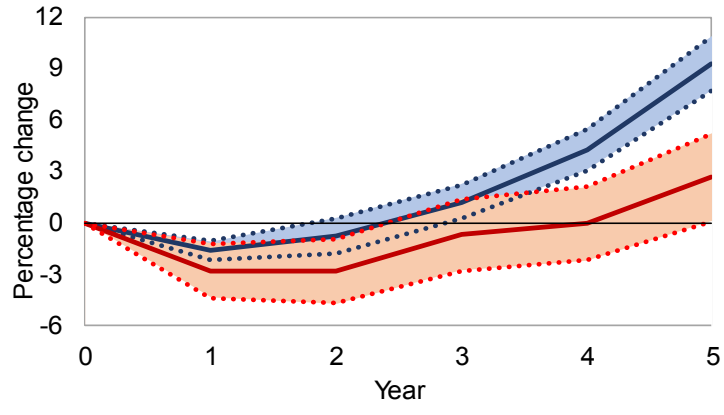

Weak balance sheets

Note: Blue line represents sample of countries that entered the recession with a strong initial balance sheet, and the red line is for those those entering the downturn with a weak balance sheet. The sample is restricted to the sample of recession episodes and the dotted lines represent the 90 percent confidence bands.

Table 3. Robustness Check: Recovery and Fiscal Policy in the Aftermath of Economic Recessions

\begin{tabular}{|c|c|c|c|c|c|c|c|c|c|c|}
\hline & \multicolumn{5}{|c|}{ Real GDP Per Capita } & \multicolumn{5}{|c|}{ Real Government Expenditure Per Capita } \\
\hline & Year 1 & Year 2 & Year 3 & Year 4 & Year 5 & Year 1 & Year 2 & Year 3 & Year 4 & Year 5 \\
\hline$\theta_{s}$ & $\begin{array}{c}-1.88^{* * *} \\
(0.49)\end{array}$ & $\begin{array}{l}-0.94^{*} \\
(0.48)\end{array}$ & $\begin{array}{l}1.03^{*} \\
(0.67)\end{array}$ & $\begin{array}{c}3.88^{* * *} \\
(0.95)\end{array}$ & $\begin{array}{c}9.00^{* * *} \\
(1.29)\end{array}$ & $\begin{array}{c}3.64^{* * *} \\
(1.12)\end{array}$ & $\begin{array}{c}8.44^{* * *} \\
(2.16)\end{array}$ & $\begin{array}{c}13.81^{* * *} \\
(1.94)\end{array}$ & $\begin{array}{c}24.23^{* * *} \\
(7.21)\end{array}$ & $\begin{array}{c}33.36^{* * *} \\
(7.84)\end{array}$ \\
\hline$\theta_{w}$ & $\begin{array}{c}-2.15^{* *} \\
(0.78)\end{array}$ & $\begin{array}{c}-2.19 * * \\
(0.75)\end{array}$ & $\begin{array}{c}0.23 \\
(1.15)\end{array}$ & $\begin{array}{c}1.21 \\
(1.54)\end{array}$ & $\begin{array}{l}3.61^{* *} \\
(1.50)\end{array}$ & $\begin{array}{l}2.69^{*} \\
(1.73)\end{array}$ & $\begin{array}{c}2.28 \\
(3.53)\end{array}$ & $\begin{array}{l}3.60^{*} \\
(3.46)\end{array}$ & $\begin{array}{c}-5.44 \\
(10.97)\end{array}$ & $\begin{array}{c}2.11 \\
(8.59)\end{array}$ \\
\hline$R^{2}$ & 0.76 & 0.71 & 0.66 & 0.77 & 0.86 & 0.69 & 0.73 & 0.78 & 0.74 & 0.83 \\
\hline$\theta_{S}=\theta_{W}(p$ value $)$ & 0.83 & 0.32 & 0.66 & 0.29 & 0.07 & 0.74 & 0.30 & 0.08 & 0.12 & 0.08 \\
\hline Peaks & 53 & 53 & 52 & 52 & 42 & 53 & 53 & 52 & 52 & 42 \\
\hline
\end{tabular}

Note: The table reports the estimations using the Local Projections Model. The first five columns present the coefficients for real GDP per capita and the second five represent those for real government expenditure per capita as dependent variables (both cumulative changes starting from the peak before economic recessions). The regressions also include fixed effects that are not reported. However, control variables are excluded from these regressions. Robust standard errors are reported in the second row of each line where ${ }^{*}, * *{ }^{* * *}$ denote $p$-values less than 0.32 ( 1 standard deviation), 0.05 ( 2 standard deviations), and 0.01 ( 3 standard deviations) percent respectively. 


\section{Box 1. Country Case: Evolution of Public Sector Balance Sheet in Kazakhstan}

The 2014 oil price shock in Kazakhstan provides an example of how a country can use its balance sheet strength to provide fiscal stimulus in the aftermath of economic shocks. Kazakhstan's PSBS features large natural resources. It also features large financial assets, as the authorities have in the past saved part of their oil receipts in a sovereign wealth fund, the National Fund of the Republic of Kazakhstan (NFRK). In the public sector balance sheet this shows as risk diversification from an illiquid asset with volatile valuation (oil in the ground) to a more diversified liquid financial investment portfolio, reducing risks and improving the public sector's risk-return position. The NFRK was worth some 46 percent of GDP in 2016, with assets consisting mainly of foreign currency holdings and equities ( 80 and 20 percent respectively).

The IMF PSBS dataset enables us to study the evolution of net worth in Kazakhstan following the halving of the oil price in 2014. The oil price shock, combined with an external demand shock from Russia and China, led to a sharp exchange rate depreciation and a slowdown in growth in 2014, and deterioration of the fiscal balance from +5 percent of GDP in 2013 to -6 percent in 2015. The impact of the shock on Kazakhstan's PSBS was sizeable, by increasing the fiscal deficit, and lowering the value of the remaining oil reserves and hence natural resource wealth. However, these effects were offset by valuation effects on oil reserves and sovereign wealth fund holdings due to exchange rate depreciation, a natural hedge in the PSBS. These balance sheet effects combined with large buffers provided room for large-scale countercyclical fiscal policy. The government undertook a 10 percent of GDP fiscal stimulus between 2014-17 and provided 4 percent of GDP in financial sector support in 2017, largely financed by NFRK resources.

\section{Kazakhstan: Evolution of Net Worth (percent of 2016 GDP)}

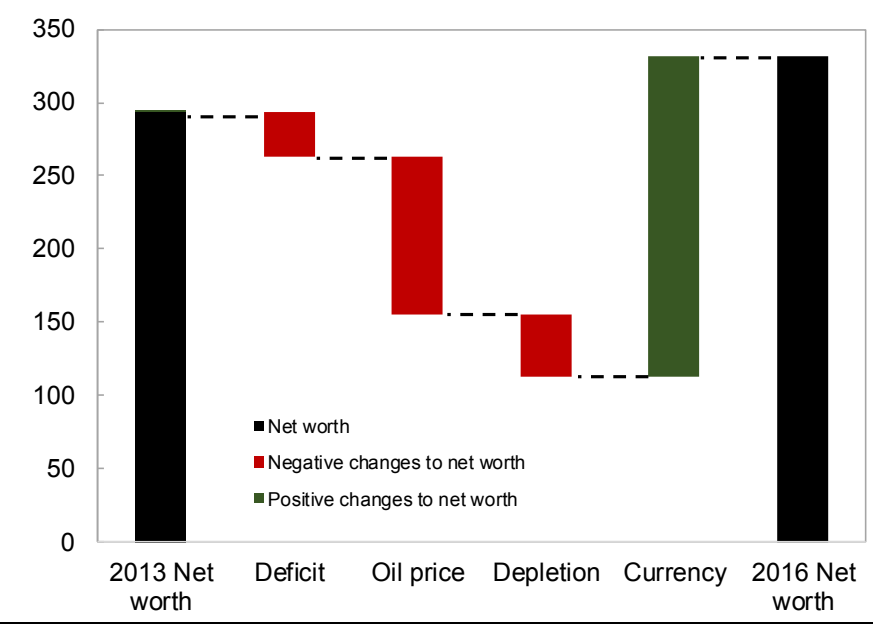




\section{CONCLUSION}

This paper introduces measures of public sector balance sheet strength and shows the macroeconomic relevance of these strength measures. The measures include the size and liquidity of assets and liabilities, their volatility and mismatches, and how they correlate with each other.

The empirical analysis shows that balance sheet strength matters both for sovereign yields and for economic resilience. In particular, the findings suggest that financial markets consider governments' asset positions in addition to debt levels in determining borrowing costs. In other words, countries cannot not easily affect their borrowing costs by incurring or repaying debt through asset accumulation or decumulation, as financial markets (partially) see through such transactions. Second, countries with stronger balance sheets experience shallower and shorter recessions compared with those with weaker balance sheets. This owe to their ability to better cushion the economy by boosting demand in a downturn through higher public expenditures.

These findings have important policy implications. While it is essential to assess a country's gross public debt stance, the fiscal policy debate could be enriched by looking at a country's entire public sector balance sheet, including the asset side. This would allow policy makers to assess how public wealth could be best used to meet a country's long-term economic goals. The empirical results also underscore the importance of building resilience and buffers in one's PSBS to counter the adverse effects of economic downturns.

Future research could take the balance sheet approach to public policy further. Such analyses would require high-quality data collection on the asset side and extension of IMF (2019) dataset to include more countries - emerging markets, in particular — and over a longer time period. Further research could also shed light on long-term sustainability of macroeconomic policies by extending the analysis to measures of intertemporal net worth, which includes future revenue and expenditure flows and hence fully accounts for prospective ageing-related liabilities. Such studies could help broaden our knowledge on the macroeconomic implications of public sector balance sheet strength. In addition, future work should explore the channels through which public sector balance sheet strength cushions recessions. 


\section{REFERENCES}

Abbas, S. A., Belhocine, N., \& ElGanainy, A. M. Horton, 2010. A historical public debt database. International Monetary Fund (No. 245). IMF Working Paper.

Akitoby, B. and T. Stratmann (2008), "Fiscal Policy and Financial Markets", Economic Journal, 118, 1971-1985.

Allen, M., C. Rosenberg, C. Keller, B. Setser, and N. Roubini. 2002. "A Balance Sheet Approach to Financial Crises." IMF Working Paper 02/210, International Monetary Fund, Washington, DC.

Alves, M., S. De Clerck, and J. Gamboa Arbelaez. 2019. "Public Sector Balance Sheet Database: Overview and Guide for Compilers and Users," forthcoming IMF Working Paper, International Monetary Fund, Washington, DC.

Ardagna, S., F. Caselli, and T. Lane (2007), "Fiscal Discipline and the Cost of Public Debt Service: Some Estimates for OECD Countries", The B.E. Journal of Macroeconomics, 7 (1), 1-35.

Auerbach, A.J. and Kotlikoff, L.J., 1987. Dynamic fiscal policy. Cambridge University Press.

Bernardini, M., and L. Forni. 2017. "Private and Public Debt: Are Emerging Markets at Risk?" IMF Working Paper 17/61, International Monetary Fund, Washington, DC.

Bova, E., R. Dippelsman, K. Rideout, and A. Schaechter. 2013. "Another Look at Government's Balance Sheets: The Role of Nonfinancial Assets." IMF Working Paper 13/95, International Monetary Fund, Washington, DC.

Brede, M., and C. Henn. 2018. "Finland's Public Sector Balance Sheet: A Novel Approach to Analysis of Public Finance." IMF Working Paper 18/78, International Monetary Fund, Washington, DC.

Bry, G. and C. Boschan. 1971. "Cyclical Analysis of Time Series: Selected Procedures and Computer Programs." The National Bureau of Economic Research, Cambridge, MA.

Buiter, W.H. 1983. "Measurement of the Public-sector Deficit and its Implications for Policy Evaluation and Design." IMF Staff Papers 30(2): 306-349, International Monetary Fund, Washington, DC.

Chinn, M.D. and J.A. Frankel (2005), "The Euro Area and World Interest Rates", University of California, Santa Cruz Working Paper Series, 1031.

Dell'Erba, S., R. Hausmann, and U. Panizza (2013), "Debt levels, debt composition, and sovereign spreads in emerging and advanced economies", Oxford Review of Economic Policy, 29 (3), 518-547.

Driscoll, J. C., and A. C. Kraay. 1998. "Consistent Covariance Matrix Estimation with Spatially Dependent Panel Data." Review of Economics and Statistics 80(4): 549-560.

Gruber, J.W., and S.B. Kamin. 2012. "Fiscal Positions and Government Bond Yields in OECD Countries." Journal of Money, Credit, and Banking, 44(8): 1563-1587. 
Hadzi-Vaskov, M, and L.A. Ricci. 2016. "Does Gross or Net Debt Matter More for Emerging Market Spreads?" IMF Working Paper 16/246, International Monetary Fund, Washington, DC.

Haugh, D., P. Ollivaud, and D. Turner (2009), "What Drives Sovereign Risk Premiums? An Analysis of Recent Evidence from the Euro Area", OECD Economics Department Working Papers, 718, OECD, Paris.

Henao-Arbelaez, C., and N. Sobrinho. 2017. "Government Financial Assets and Debt Sustainability." IMF Working Paper 17/173, International Monetary Fund, Washington, DC.

International Monetary Fund. 2012. "Fiscal Frameworks for Resource Rich Developing Countries." IMF Staff Discussion Note 12/04, Washington, DC. https://www.imf.org/ /media/Websites/IMF/imported-full-textpdf/external/pubs/ft/sdn/2012/ sdn1204.ashx

International Monetary Fund. 2019. Public Sector Balance Sheet Database.

International Monetary Fund. 2018. "Fiscal Monitor: Managing Public Wealth." Washington, DC. International Monetary Fund. 2016. "Fiscal Monitor: Debt - Use It Wisely." Washington, DC. Jaramillo, L., C. Mulas-Granados and E. Kimani. 2017. "Debt Spikes and Stock Flow Adjustments: Emerging Economies in Perspective." Journal of Economics and Business, vol 94, C 1-14.

Jaramillo, L. and A. Weber (2013), "Bond Yields in Emerging Economies: It Matter What State you are in", Emerging Markets Review, 17, 169-185.

Jordà, O. 2005. "Estimation and Inference of Impulse Responses by Local Projections." American Economic Review 95: pp. 161-82.

Jordà, O., M. Schularick, and A.M. Taylor, 2016, "Sovereigns Versus Banks: Credit, Crises, and Consequences," Journal of the European Economic Association, 14 (1), 45-79.

Mauro, P., R. Romeu, A. Binder, and A. Zaman. 2015. "A Modern History of Fiscal Prudence and Profligacy." Journal of Monetary Economics 76 (C): 55-70.

Reinhart, Carmen M., and Kenneth S. Rogoff. 2010. "Growth in a Time of Debt." American Economic Review 100, no. 2: 573-78.

Seiferling, M. and T. Shamsuddin. 2015. "Fiscal Transparency and the Performance of Government Financial Assets." IMF Working Paper 15/9, International Monetary Fund, Washington, DC.

Traa, B. 2006. "Germany: Selected Issues", Chapter 3: A Preliminary Public Sector Balance Sheet for Germany, Country Report No. 06/17, International Monetary Fund, Washington, DC.Traa, B. and A. Carare. 2007. "A Government's Net Worth." Finance and Development 44(2), International Monetary Fund, Washington, DC.

Velculescu, D. (2010). "A Leap Beyond Traditional Fiscal Indicators: Measuring Poland's Intertemporal Net Worth and Deriving its Policy Implications." Poland Selected Issues, Country Report No. 10/119, International Monetary Fund, Washington, DC. 


\section{Appendix Table 1. Government Balance Sheet and Sovereign Bond Yields (Concurrent Variables)}

\begin{tabular}{|c|c|c|c|c|c|c|c|}
\hline \multirow{2}{*}{$\begin{array}{l}\text { Full Sample } \\
\text { NW }\end{array}$} & & & & & & & \\
\hline & & & $\begin{array}{l}-0.0183^{* * *} \\
{[0.006]}\end{array}$ & & & & \\
\hline NFW & & & & $\begin{array}{l}-0.0126^{* *} \\
{[0.005]}\end{array}$ & & & \\
\hline Gross Debt & $\begin{array}{l}0.0262^{* * *} \\
{[0.007]}\end{array}$ & $\begin{array}{l}0.0230^{* * *} \\
{[0.007]}\end{array}$ & & & $\begin{array}{l}0.0093 * * \\
{[0.004]}\end{array}$ & & \\
\hline Total Asset & $\begin{array}{l}-0.0260^{* * *} \\
{[0.007]}\end{array}$ & & & & & $\begin{array}{l}-0.0214 * * \\
{[0.007]}\end{array}$ & \\
\hline Financial Assets & & $\begin{array}{l}-0.0267^{* *} \\
{[0.011]}\end{array}$ & & & & & $\begin{array}{l}-0.0235^{* *} \\
{[0.011]}\end{array}$ \\
\hline Observations & 359 & 358 & 395 & 394 & 600 & 394 & 393 \\
\hline R Squared & 0.543 & 0.536 & 0.519 & 0.505 & 0.856 & 0.514 & 0.51 \\
\hline Number of countries & 31 & 31 & 33 & 33 & 33 & 33 & 33 \\
\hline \multicolumn{8}{|l|}{ Advanced Economies } \\
\hline NW & & & $\begin{array}{l}-0.0094^{* * *} \\
{[0.003]}\end{array}$ & & & & \\
\hline NFW & & & & $\begin{array}{l}-0.0105^{* * *} \\
{[0.003]}\end{array}$ & & & \\
\hline Gross Debt & $\begin{array}{l}0.0162 * * * \\
{[0.004]}\end{array}$ & $\begin{array}{l}0.0158^{* * *} \\
{[0.004]}\end{array}$ & & & $\begin{array}{l}0.0101^{* * *} \\
{[0.003]}\end{array}$ & & \\
\hline Total Asset & $\begin{array}{l}-0.0054 \\
{[0.004]}\end{array}$ & & & & & $\begin{array}{l}-0.0026 \\
{[0.004]}\end{array}$ & \\
\hline Financial Assets & & $\begin{array}{l}-0.0125^{* *} \\
{[0.006]}\end{array}$ & & & & & $\begin{array}{l}-0.0113^{*} \\
{[0.006]}\end{array}$ \\
\hline Observations & 291 & 290 & 311 & 310 & 513 & 310 & 309 \\
\hline R Squared & 0.86 & 0.861 & 0.854 & 0.852 & 0.936 & 0.849 & 0.85 \\
\hline Number of countries & 24 & 24 & 25 & 25 & 24 & 25 & 25 \\
\hline
\end{tabular}

Note: The table respresents the fixed effects estimation results investigating the impact of balance sheet indicators on long-term government bond spreads. Total Assets exclude land and natural resources, and liabilities exclude pension liabilities for reasons of cross-country comparability. For the same reason, NW excludes all the above-mentioned and NFW excludes pension liabilities. Control variables include lagged values of Real GDP per capita growth, US 10-year bond yield, average inflation rate, short-term interest rate, general government primary balance, country- and time-fixed effects not reported in the table for brevity. The sample period is 2001-16. NFW stands for net financial worth, and NW denotes net worth.

$*, * *$, and ${ }^{* * *}$ represent statistical significance at 10,5 , and 1 percent, respectively. 
Appendix Table 2. Government Balance Sheet and Sovereign Bond Yields (Random Effects)

Dependent variable: Long term government bond yields

\begin{tabular}{|c|c|c|c|c|c|c|c|}
\hline Full Sample & & & & & & & \\
\hline Lagged NW & & & $-0.0066^{* *}$ & & & & \\
\hline & & & 0.0024 & & & & \\
\hline Lagged NFW & & & & $-0.006 * *$ & & & \\
\hline & & & & {$[0.003]$} & & & \\
\hline Lagged Gross Debt & $0.0141^{* * *}$ & $0.013^{* * *}$ & & & $0.0105^{* * *}$ & & \\
\hline & 0.0033 & {$[0.003]$} & & & 0.0019 & & \\
\hline Lagged Total Asset & $-0.0087^{* * *}$ & & & & & $-0.009 * * *$ & \\
\hline & 0.0026 & & & & & {$[0.003]$} & \\
\hline Lagged Financial Assets & & $-0.007^{* * *}$ & & & & & $-0.010 * * *$ \\
\hline & & {$[0.003]$} & & & & & {$[0.003]$} \\
\hline Observations & 409 & 415 & 445 & 447 & 685 & 448 & 454 \\
\hline Number of countries & 31 & 31 & 33 & 33 & 33 & 33 & 33 \\
\hline Advanced Economies & & & & & & & \\
\hline Lagged NW & & & $-0.005^{* * *}$ & & & & \\
\hline & & & {$[0.001]$} & & & & \\
\hline Lagged NFW & & & & $-0.006 * * *$ & & & \\
\hline & & & & {$[0.001]$} & & & \\
\hline Lagged Gross Debt & $0.015^{* * *}$ & $0.014^{* * *}$ & & & $0.012^{* * *}$ & & \\
\hline & {$[0.002]$} & [0.002] & & & {$[0.002]$} & & \\
\hline Lagged Total Asset & $-0.003 * *$ & & & & & $-0.003 * *$ & \\
\hline & {$[0.001]$} & & & & & {$[0.001]$} & \\
\hline Lagged Financial Assets & & $-0.004 * * *$ & & & & & $-0.007^{* * *}$ \\
\hline & & {$[0.002]$} & & & & & {$[0.002]$} \\
\hline Observations & 328 & 334 & 348 & 350 & 579 & 351 & 357 \\
\hline Number of countries & 24 & 24 & 25 & 25 & 24 & 25 & 25 \\
\hline Emerging Markets & & & & & & & \\
\hline Lagged NW & & & $-0.025^{* * *}$ & & & & \\
\hline & & & {$[0.009]$} & & & & \\
\hline Lagged NFW & & & & -0.013 & & & \\
\hline & & & & {$[0.010]$} & & & \\
\hline Lagged Gross Debt & $0.041^{* *}$ & 0.008 & & & 0.006 & & \\
\hline & [0.019] & {$[0.022]$} & & & {$[0.015]$} & & \\
\hline Lagged Total Asset & $-0.031 * * *$ & & & & & $-0.024 * * *$ & \\
\hline & {$[0.010]$} & & & & & [0.009] & \\
\hline Lagged Financial Assets & & $-0.046 *$ & & & & & $-0.041^{* *}$ \\
\hline & & {$[0.026]$} & & & & & {$[0.019]$} \\
\hline Observations & 81 & 81 & 97 & 97 & 106 & 97 & 97 \\
\hline Number of countries & 7 & 7 & 8 & 8 & 9 & 8 & 8 \\
\hline Note: The table respresent & the random $\mathrm{e}$ & effects es & nation resu & Its investiga & ting the imp & act of bala & cce sheet \\
\hline indicators on long-term go & ernment bon & nd spread & Total Assets & s exclude lar & nd and natu & ral resourc & es, and \\
\hline liabilities exclude pension & iabilities for & r reasons & cross-cour & ntry compar & ability. For & the same re & son, NW \\
\hline excludes all the above-ment & ioned and $\mathrm{N}$ & NFW exclud & s pension I & iabilities. Cc & ontrol varia & bles includ & Real GDP \\
\hline per capita growth, US $10-y e$ & ar bond yield & $\mathrm{d}$, average & nflation rat & e, short-term & n interest ra & te, general & sovernment \\
\hline primary balance, country- a & nd time-fixed & ed effects $n$ & t reported i & $\mathrm{n}$ the table $\mathrm{f}$ & or brevity. $T$ & he sampl & eriod is \\
\hline 2001-16. NFW stands for $n$ & t financia & worth, ar & denotes & 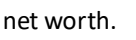 & & & \\
\hline$*, * *$, and ${ }^{* * *}$ represent $\mathrm{s}$ & istical sig & ficanc & anc & tili, & & & \\
\hline
\end{tabular}




\section{AnNex: Balance Sheet Strength: Methodology}

\section{Risk Adjusted Assets and Liabilities}

As discussed in the text, risk-adjusted assets and liabilities provide a measure of the assets and liabilities corrected for their riskiness or underlying volatility. The measures are based on estimates of the volatility of each asset (liability) class relative to the sum of the volatilities of all asset and liability components.

To construct the measures, first a measure of valuation changes in each of the asset and liability items is made. ${ }^{25}$ To do so, transactions are deducted from total changes in the value of these items. Next, the relative volatility of valuation changes of individual items is defined as their riskiness, and labeled as the item's risk weight (RW):

$R W_{i}=\frac{\sigma_{i}^{2}}{\sum_{i} \sigma_{i}^{2 \prime}}$

where $i$ is the indicator for a specific item of assets or liabilities. Note that one index for assets and liabilities is used to indicate that a balance sheet item's volatility is scaled relative to all other balance sheet items, be they assets or liabilities. These risk weights are calculated on a sample of European countries for which detailed data on transactions and valuation changes of individual general government balance sheet items is available. Countries included in the analysis are: Austria, Belgium, Bulgaria, Croatia, Cyprus, Czech Republic, Denmark, Estonia, Finland, France, Germany, Hungary, Ireland, Italy, Latvia, Lithuania, Luxembourg, Malta, the Netherlands, Norway, Poland, Portugal, Romania, Slovak Republic, Slovenia, Spain, Sweden, and the United Kingdom.

The resulting risk weights are available in the Annex Table. Using these risk weights and the size of individual balance sheet items, a comprehensive measure of the riskiness of the asset and liability side of the balance sheet are constructed, which are denoted as $\sum_{\mathrm{i}} \mathrm{RW}_{i} \mathrm{~A}_{i}$ and $\sum_{\mathrm{i}} \mathrm{RW}_{i} \mathrm{~L}_{i}$. Last, these values are deducted from total assets and liabilities to get risk-adjusted assets $(R A A)$ and liabilities (RAL):

$$
\begin{aligned}
& R A A=\sum_{\mathrm{i}} \mathrm{A}_{i}-\sum_{\mathrm{i}} \mathrm{RW}_{i} \mathrm{~A}_{i}, \\
& R A L=\sum_{\mathrm{i}} \mathrm{L}_{i}-\sum_{\mathrm{i}} \mathrm{RW}_{i} \mathrm{~L}_{i} .
\end{aligned}
$$

\footnotetext{
25 For reasons of cross-country comparability, total assets are analyzed excluding land and natural resources and total liabilities excluding pension liabilities.
} 


\begin{tabular}{|c|c|}
\hline 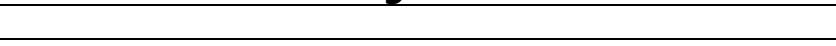 & Weight \\
\hline \multicolumn{2}{|l|}{ Financial assets by instrument } \\
\hline Monetary gold and SDRs & 0.000 \\
\hline Currency and deposits & 0.000 \\
\hline Debt securities & 0.049 \\
\hline Loans & 0.064 \\
\hline Equity and investment fund shares & 0.564 \\
\hline Insurance, pension, and standardized guarantee schemes & 0.000 \\
\hline Financial derivatives and employee stock options & 0.049 \\
\hline Other accounts receivable & 0.049 \\
\hline \multicolumn{2}{|l|}{ Liabilities by instrument } \\
\hline SDRs & 0.000 \\
\hline Currency and deposits & 0.000 \\
\hline Debt securities & 0.000 \\
\hline Loans & 0.122 \\
\hline Equity and investment fund shares & 0.000 \\
\hline Insurance, pension, and standardized guarantee schemes & 0.000 \\
\hline Financial derivatives and employee stock options & 0.014 \\
\hline Other accounts payable & 0.090 \\
\hline Sum of weights & 1.000 \\
\hline
\end{tabular}

Note: Risk weight of each instrument is the standard deviation of valuation changes in that instrument relative to the sum of standard deviations of all asset and liability components. SDRs = Special Drawing Rights

\section{Natural Hedge}

As net financial worth is defined as financial assets net of liabilities, valuation changes in net financial worth (that is, changes resulting from other economic flows) can be represented as:

$$
O E F_{N F W}=O E F_{F A}-O E F_{L \prime}
$$

Where $O E F_{F A}, O E F_{L}$, and $O E F_{N F W}$ denote other economic flows in financial assets, liabilities, and net financial worth, respectively, all expressed in percent of GDP. Then:

$$
\sigma_{N F W}^{2}=\sigma_{F A}^{2}+\sigma_{L}^{2}-2 \operatorname{Cov}_{F A L}
$$

where $F A$ denotes financial assets and $L$ denotes liabilities. The equation shows how the volatility of net financial worth is dampened by the covariance between financial assets and liabilities.

To come up with a normalized measure of the volatility in net financial worth, the volatility of net financial worth is divided by the standard deviations of financial assets and liabilities, resulting in a unit-less measure-similar to the measure of correlation. The relative volatility of NFW to the volatility of financial assets and liabilities is presented as $\sigma_{n}$ :

$$
\sigma_{n}=\frac{\sigma_{N F W}^{2}}{\sigma_{F A} \sigma_{L}}
$$


This is the natural hedge measure. It can be rewritten by plugging equation (1) into (2):

$$
\sigma_{n}=\frac{\sigma_{N F W}^{2}}{\sigma_{F A} \sigma_{L}}=\frac{\sigma_{F A}}{\sigma_{L}}+\frac{\sigma_{L}}{\sigma_{F A}}-2 \frac{\operatorname{Cov}_{F A L}}{\sigma_{F A} \sigma_{L}}, \quad \text { or } \quad \sigma_{n}=x+\frac{1}{x}-2 \operatorname{Cor}_{F A L^{\prime}}
$$

where $\mathrm{x}=\frac{\sigma_{F A}}{\sigma_{L}}$, and $\operatorname{Cor}_{F A L}$ represents the correlation between financial assets and liabilities.

The relative standard deviations ( $x$ and $\frac{1}{x}$ ) are proxies for the contribution of size mismatch between financial assets and liabilities to the variation in net financial worth-if one side of the balance sheet is much bigger than the other side, its variations will dominate the variations in net financial worth. $\operatorname{Cor}_{F A L}$ represents how valuation changes in financial assets and liabilities move together. Figure 2 in the main text displays exactly these different elements: The relative volatility of net financial worth $\left(\sigma_{n}\right)$, the relative volatility of financial assets and liabilities $\left(x+\frac{1}{x}\right)$, and the relative volatility increase or decrease $\left(2 \mathrm{Cor}_{F A L}\right)$. 